\title{
METODE PENAPISAN CABAI (CAPSICUM ANNUUM L.) UNTUK KETAHANAN TERHADAP CHILLI VEINAL MOTTLE VIRUS (Chi VMV) DAN CUCUMBER MOSAIC VIRUS (CMV)
}

\author{
Latifah $^{1}$, Sri Hendrastuti Hidayat ${ }^{2}$ dan Sriani Sujiprihati ${ }^{3}$
}

\begin{abstract}
Screening Method for Chilli Veinal Mottle Virus (Chi VMV) and Cucumber Mosaic Virus (CMV) Resistance in Chillipepper. ChiVMV and CMV have been reported as the causal agents of main diseases in chillipepper in Indonesia and other Asian countries. Mix infection of this two viruses was commonly occurred in the field, causing severe disease. The use of resistance varieties has been proposed for dealing with the yield losses causing by the viruses. Breeding program is undergoing for development of chillipepper varieties resistant to ChiVMV and CMV. Methodology for routine screening activity of chillipepper for resistance to both ChiVMV and CMV needs to be established. This research was conducted in Cikabayan Glass House and Plant Virology Laboratory, Plant Protection Department, Bogor Agricultural University from May 2006 to June 2007. Aim of the research was to develop screening method for simultaneous infection by the two viruses, ChiVMV and CMV. Inoculation of ChiVMV and CMV was done by single inoculation or repetitive inoculation methods. In both methods, ChiVMV and CMV were inoculated in different sequences, either ChiVMV or CMV first. The result showed that incubation period was shorter when CMV was inoculated in advance both in single and repetitive inoculation method. Mosaic, mottle and malformation type symptom was observed in infected plants. Based on disease incidence, infection of ChiVMV was higher compared to CMV in repetitive inoculation as well as in single inoculation. Repetitive inoculation methods with virus sequence ChiVMV-CMV-ChiVMV-CMV was selected for resistance evaluation of chillipepper genotypes.
\end{abstract}

Key words : ChiVMV, CMV, chillipepper, single inoculation, repetitive inoculation

\section{PENDAHULUAN}

Cabai (Capsicum annuum L.) merupakan salah satu komoditas unggulan hortikultura di Indonesia karena merupakan salah satu jenis sayuran yang mempunyai potensi untuk dikembangkan (Direktorat Jenderal Bina Produksi Hortikultura 2007). Penyakit cabai yang disebabkan oleh infeksi virus merupakan faktor yang sangat penting yang menyebabkan produksi cabai menurun selain faktor iklim.

Menurut Laemmlen (2004) dan Green \& Kim (1994), virus yang dapat menginfeksi tanaman cabai terdiri atas cucumber mosaic virus (CMV), chilli veinal mottle virus (ChiVMV), alfalfa mosaic virus (AMV), tobacco etch virus (TEV), tobacco mosaic virus (TMV), pepper mottle virus (PeMV), beet curly top virus (BCTV), tomato spotted wilt virus (TSWV) dan potato virus Y (PVY). Taufik et al. (2005) selanjutnya melaporkan bahwa ChiVMV dan CMV merupakan virus utama yang menginfeksi tanaman cabai di Indonesia.

Gejala infeksi kedua virus ini di lapangan sangat sulit dibedakan karena tanaman dapat terinfeksi oleh banyak virus secara bersamaan sehingga gejala yang ditimbulkan menjadi kompleks (Zhang, 2005).

Pengendalian penyakit karena infeksi virus pada umumnya relatif sulit dilakukan. Metode pengendalian virus yang dapat diharapkan keberhasilannya adalah dengan menggunakan varietas tahan (Dolores, 1996). Namun permasalahan yang dihadapi adalah belum adanya varietas cabai yang tahan terhadap ChiVMV dan CMV (Taufik, 2005).

Peran para pemulia dalam usaha perakitan varietas baru yang memiliki ketahanan terhadap berbagai virus sangat penting. Varietas tahan dapat dihasilkan melalui seleksi plasma nutfah dan persilangan tetua terpilih. Sifat tahan ini dapat berasal dari kultivar komersial, spesies liar sekerabat, spesies lain dalam satu genus atau genus lain (Niks \& Lindhout, 2006). Salah satu langkah awal yang harus dilakukan dalam kegiatan pemuliaan tanaman untuk perakitan varietas tahan adalah melakukan penapisan (screening) untuk memperoleh tetua yang tahan (Yunianti, 2007).

Dalam melakukan penapisan ketahanan diperlukan metode penapisan yang efektif. Selama ini

\footnotetext{
${ }^{1}$ Fakultas Pertanian, Universitas Malikussaleh, Lhokseumawe 24351

${ }^{2}$ Departemen Proteksi Tanaman, Fakultas Pertanian, Institut Pertanian Bogor, Jl. Kamper, Kampus Darmaga, Bogor 16680, e-mail: srihendrastutihidayat@gmail.com

${ }^{3}$ Departemen Agronomi dan Hortikultura, Fakultas Pertanian, Institut Pertanian Bogor, Kampus IPB Darmaga, Bogor 16680
} 
penapisan ketahanan terhadap beberapa penyakit pada tanaman sering dilakukan secara terpisah untuk masing-masing patogen. Metode seperti ini sangat tidak efektif jika tujuan akhir pemuliaan tanaman adalah ketahanan terhadap beberapa jenis penyakit, termasuk ketahanan terhadap beberapa jenis virus. Oleh karena itu penelitian untuk mendapatkan metode penapisan ketahanan yang efektif pada cabai perlu dilakukan sehingga mempermudah dalam mengevaluasi ketahanan cabai terhadap beberapa virus secara bersamaan.

Penelitian ini bertujuan untuk mendapatkan metode penapisan yang efektif untuk mengevaluasi ketahanan tanaman cabai terhadap dua virus utama yaitu ChiVMV dan CMV.

\section{METODE PENELITIAN}

Penelitian ini dilaksanakan pada bulan Mei 2006 sampai Juni 2007 di rumah kaca Cikabayan dan Laboratorium Virologi Tumbuhan, Departemen Proteksi Tanaman, Fakultas Pertanian, Institut Pertanian Bogor.

Perbanyakan sumber inokulum ChiVMV dan CMV. Isolat ChiVMV yang digunakan dalam penelitian ini adalah isolat asal Cikabayan yang merupakan isolat koleksi Laboratorium Virologi Tumbuhan, Fakultas Pertanian IPB; sedangkan isolat CMV berasal dari Balai Penelitian Tanaman Sayuran, Lembang. Tanaman yang digunakan untuk perbanyakan sumber inokulum ChiVMV ialah paprika (C. annuum var. Grossum) dan untuk perbanyakan CMV digunakan tembakau (Nicotiana glutinosa). Perbanyakan sumber inokulum dilakukan secara mekanis mengikuti metode baku Zhang (2005) dan Dijkstra \& de Jager (1998). Daun yang terinfeksi masing-masing virus ditimbang kemudian digerus dalam mortar steril dengan diberi bufer fosfat $(0,01$ $\mathrm{M}$; pH 7.0) dengan perbandingan $1 \mathrm{~g}$ daun terinfeksi virus per $5 \mathrm{ml}$ larutan bufer fosfat $(1: 5 \mathrm{~b} / \mathrm{v})$. Cairan perasan ini segera diinokulasikan ke tanaman sehat yaitu pada 2 helai daun termuda. Sebelum diinokulasi ditaburi serbuk karborundum (600 mesh) pada bagian permukaan atas daun, kemudian cairan perasan yang mengandung virus dioleskan dengan menggunakan cotton bud steril pada permukaan daun yang dimulai dari pangkal daun ke ujung daun secara searah tanpa mengulangi pada daerah yang sama. Setelah pengolesan segera dilakukan pembilasan pada daun untuk membersihkan sisa-sisa cairan perasan yang melekat pada permukaan daun menggunakan air mengalir. Tanaman dipelihara di dalam rumah kaca kedap serangga. Tanaman yang menunjukkan gejala digunakan sebagai sumber inokulum.

Persiapan tanaman cabai. Tanaman cabai yang digunakan dalam percobaan ini terdiri atas empat genotipe yaitu PBC 275, PBC 521, VC 246 (benih berasal dari Asian Vegetable Research and Development Center) (AVRDC) dan Jatilaba (benih berasal dari Bagian Genetika dan Pemuliaan Tanaman, Departemen Agronomi dan Hortikultura, Fakultas Pertanian IPB). Benih cabai dari masing-masing genotipe disemai di dalam wadah semai yang berisi tanah dan pupuk organik steril. Setelah tanaman berumur empat minggu tanaman siap untuk diinokulasi dengan ChiVMV dan CMV. Teknik inokulasi ChiVMV dan CMV dilakukan secara mekanis.

Metode inokulasi. Inokulasi ChiVMV dan CMV dilakukan dengan cara inokulasi tunggal dan inokulasi berulang. Pada metode inokulasi tunggal masingmasing virus hanya diinokulasikan satu kali saja pada tanaman yang diuji; sementara pada metode inokulasi berulang, inokulasi masing-masing virus dilakukan dua kali. Tahapan inokulasi untuk masing-masing metode adalah sebagai berikut :

Inokulasi tunggal. Inokulasi tunggal dengan ChiVMV dan CMV dilakukan dengan dua cara, yaitu: (1) Cairan perasan tanaman yang mengandung ChiVMV terlebih dahulu diinokulasikan pada daun tanaman cabai yang diuji, tiga hari kemudian diinokulasi dengan CMV; (2) Cara inokulasi yang kedua sama dengan cara yang pertama hanya dilakukan inokulasi dengan CMV terlebih dahulu kemudian ChiVMV.

Inokulasi berulang. Perlakuan inokulasi berulang dengan ChiVMV dan CMV dilakukan dengan dua cara, yaitu: (1) Cairan perasan tanaman yang mengandung ChiVMV terlebih dahulu diinokulasikan pada daun tanaman cabai yang diuji kemudian diinokulasi dengan CMV, perlakuan inokulasi ChiVMV dan CMV diulang sebanyak dua kali, dengan jarak waktu antara inokulasi ChiVMV dengan 
CMV adalah tiga hari; (2) Cara inokulasi yang kedua sama dengan cara yang pertama hanya dilakukan inokulasi dengan CMV terlebih dahulu kemudian ChiVMV.

Jumlah tanaman cabai yang diinokulasi untuk setiap genotipe adalah 25 tanaman dan 5 tanaman kontrol. Untuk perlakuan kontrol tanaman diinokulasi dengan bufer fosfat. Pengamatan dilakukan terhadap masa inkubasi, gejala yang muncul dan kejadian penyakit berdasarkan ELISA.

Deteksi ChiVMV dan CMV pada tanaman cabai. Deteksi ChiVMV dan CMV pada tanaman cabai yang diuji dilakukan dengan DAS-ELISA (Double Antibody Sandwich Enzyme Linked Immunosorbent Assay) mengikuti metode Clark \& Adams (1977). Sebanyak $1 \mu 1$ antibodi (ChiVMV, CMV) diencerkan ke dalam $1000 \mu$ l coating buffer ( $1,59 \mathrm{~g}$ sodium carbonate, 2,93 $\mathrm{g}$ sodium bicarbonate, $0,2 \mathrm{~g}$ sodium azide dilarutkan dalam $1000 \mathrm{ml} \mathrm{H}_{2} \mathrm{O}, \mathrm{pH}$ 9,6) dan dimasukkan ke dalam plat mikrotiter sebanyak $100 \mu 1$ tiap sumuran plat mikrotiter, kemudian diinkubasikan pada suhu 37 ${ }^{\circ} \mathrm{C}$ selama 2 sampai 4 jam. Selanjutnya plat mikrotiter dicuci sebanyak 5-7 kali dengan PBST (8 g sodium chloride, 0,2 g monobasic potassium phosphate, 1,15 $\mathrm{g}$ dibasic sodium phosphate, $0,2 \mathrm{~g}$ potassium chloride, $0,2 \mathrm{~g}$ sodium azide dan $0,5 \mathrm{~g}$ tween-20 yang dilarutkan dalam $1000 \mathrm{ml} \mathrm{H}_{2} \mathrm{O}, \mathrm{pH}$ 7,4). Sampel tanaman cabai yang terinfeksi digerus dalam sample extraction buffer ( $8 \mathrm{~g}$ sodium chloride, $0,2 \mathrm{~g}$ monobasic potassium phosphate, $1,15 \mathrm{~g}$ dibasic sodium phosphate, $0,2 \mathrm{~g}$ potassium chloride, $0,2 \mathrm{~g}$ sodium azide, dan 0,5 g tween-20, 2 g Polyvinyl pyrrolidone yang dilarutkan dalam $1000 \mathrm{ml} \mathrm{H}_{2} \mathrm{O}, \mathrm{pH}$ $7,4)$ dengan perbandingan $1: 5(\mathrm{~b} / \mathrm{v})$. Cairan perasan tanaman yang dihasilkan diambil sebanyak $100 \mu 1$ kemudian dimasukkan ke dalam sumuran plat mikrotiter dan diinkubasikan selama semalam pada suhu $4{ }^{\circ} \mathrm{C}$. Selanjutnya plat mikrotiter dicuci lagi sebanyak 5-7 kali dengan PBST. Setelah dicuci dengan PBST, ke dalam sumuran plat mikrotiter diisi $100 \mu 1$ enzim konjugat yang sudah diencerkan dengan conjugate buffer ( $2 \mathrm{~g}$ polyvinyl pyrrolidone, 0,2 g egg albumin yang dilarutkan dalam $100 \mathrm{ml}$ PBST, $\mathrm{pH} 7,4$ ) dan diinkubasi pada $37^{\circ} \mathrm{C}$ selama 4 jam. Selanjutnya dilakukan pencucian dengan PBST sebanyak 5-7 kali, sumuran plat mikrotiter kemudian diisi dengan $100 \mu 1$ larutan substrat p-nitrophenyl phosphate (PNP) $(97 \mathrm{ml}$ diethanolamine, $600 \mathrm{ml} \mathrm{H} \mathrm{H}_{2} \mathrm{O}, 0,2 \mathrm{~g}$ sodium azide dilarutkan dalam $1000 \mathrm{ml} \quad \mathrm{H}_{2} \mathrm{O}, \quad \mathrm{pH}$ 9,8) dan diinkubasi pada suhu ruang selama 60 menit sambil diamati terjadinya perubahan warna pada sumuran plat mikrotiter. Pengamatan secara kuantitatif dilakukan dengan pembacaan nilai absorban pada panjang gelombang $405 \mathrm{~nm}$ dengan ELISA Reader. Reaksi dihentikan dengan menambahkan larutan $\mathrm{NaOH} 3 \mathrm{M}$ sebanyak $50 \mu 1$ ke dalam masing-masing sumuran. Kontrol negatif yang digunakan adalah tanaman sehat dan bufer, sedangkan kontrol positif digunakan tanaman paprika yang terinfeksi ChiVMV dan tanaman tembakau yang terinfeksi CMV.

Deteksi dilakukan dua kali yaitu dua minggu setelah inokulasi terakhir dan dua minggu setelah deteksi yang pertama. Deteksi dilakukan pada sampel daun termuda, sampel daun diambil secara komposit dengan mengumpulkan lima tanaman yang bergejala sama.

Berdasarkan hasil deteksi ELISA dihitung kejadian penyakit menggunakan rumus sebagai berikut :

$$
\mathrm{KP}=\frac{n}{N} \times 100 \%
$$

\section{Keterangan:}

KP : kejadian penyakit

$\mathrm{n} \quad$ : jumlah tanaman positif ELISA

$\mathrm{N} \quad$ : jumlah tanaman yang diinokulasi

\section{HASIL DAN PEMBAHASAN}

Masa inkubasi dan gejala infeksi virus pada tanaman cabai. Tanaman-tanaman dari genotipe VC 246 tidak menunjukkan gejala hingga akhir pengamatan baik pada perlakuan metode inokulasi tunggal maupun berulang. Tiga genotipe lainnya, PBC 275, PBC 521 dan Jatilaba juga memberikan respon yang tidak berbeda untuk perlakuan metode inokulasi tunggal maupun berulang. Masa inkubasi pada genotipe PBC 275 cenderung lebih cepat; sementara pada genotipe PBC 521 cenderung lebih lambat (Gambar 1 dan 2).

Secara umum gejala yang muncul pada tanaman ialah belang dan mosaik. Tanaman mengalami pemucatan pada daun yang dimulai dari pangkal daun dan menyebar ke ujung daun (mosaik). Gejala lain yang teramati adalah penebalan warna tulang daun yang diikuti dengan penebalan jaringan daun yang terlihat dengan adanya daerah daun yang berwarna lebih tua dibandingkan dengan jaringan di 
PBC 275

$\mathbb{N}$ Tunggal (ChiVMV-CMV)

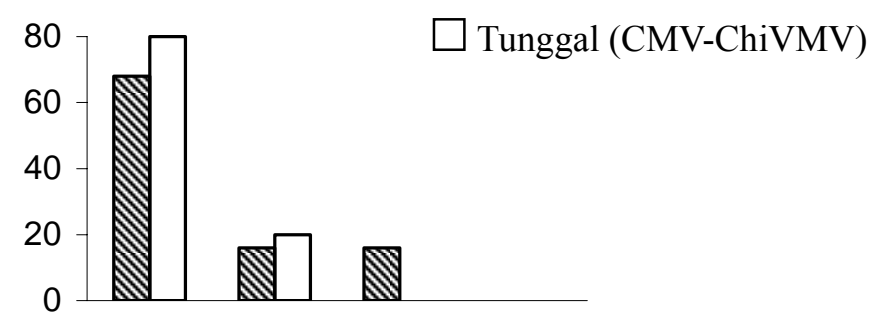

PBC 521

$\frac{d}{0}$
$\frac{0}{0}$
$\frac{2}{0}$
$\frac{1}{1}$

Jatilaba

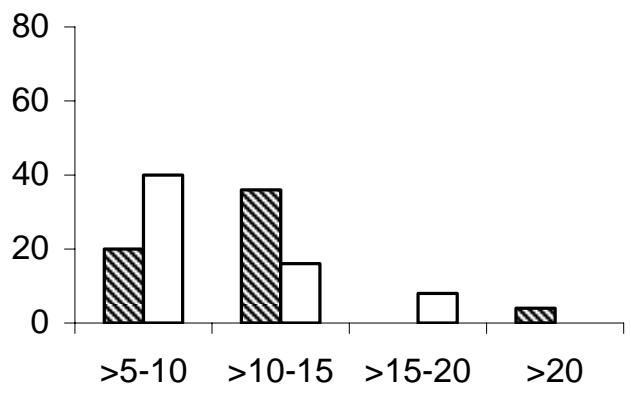

Masa inkubasi (hari)

Gambar 1. Masa inkubasi virus pada genotipe PBC 275, PBC 521 dan Jatilaba dengan perlakuan metode inokulasi tunggal. Genotipe VC 246 tidak menimbulkan gejala sampai akhir pengamatan (sehingga grafik tidak ditampilkan). 


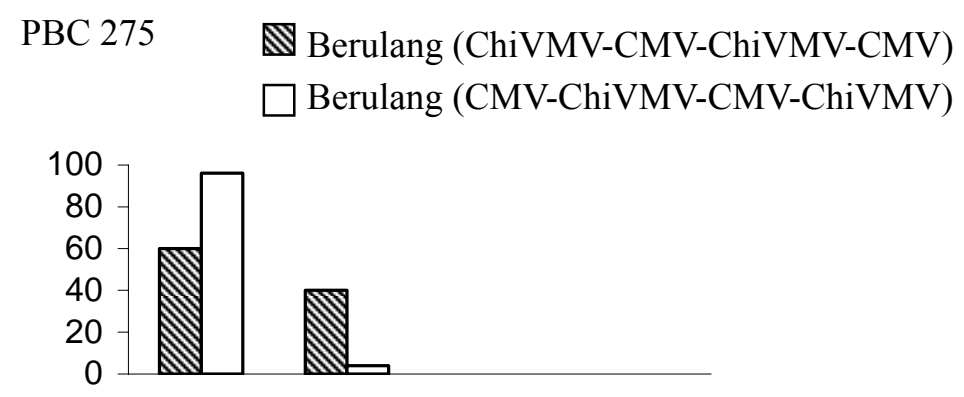

PBC 521

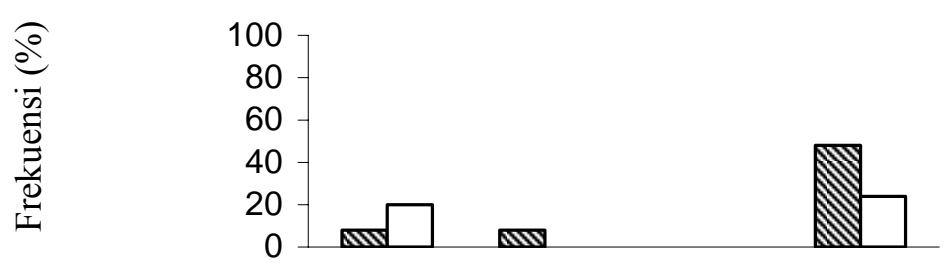

Jatilaba

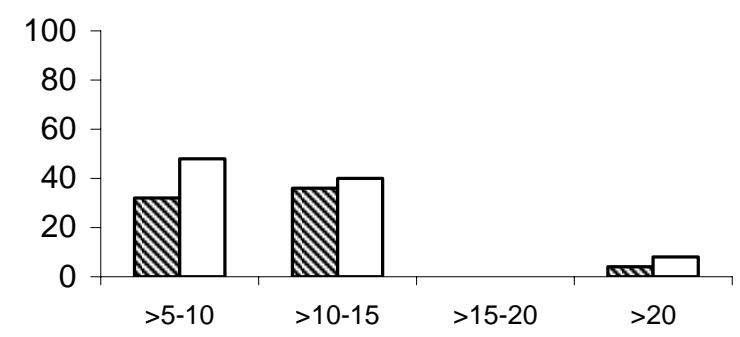

Masa inkubasi (hari)

Gambar 2. Masa inkubasi virus pada genotipe PBC 275, PBC 521 dan Jatilaba dengan perlakuan metode inokulasi berulang. Genotipe VC 246 tidak menimbulkan gejala sampai akhir pengamatan (sehingga grafik tidak ditampilkan). 
sekitarnya (belang) sampai akhirnya terjadi malformasi daun.

Tampak kecenderungan gejala belang lebih dominan pada perlakuan inokulasi dengan ChiVMV lebih dahulu. Gejala yang muncul pada genotipe PBC 275 dan Jatilaba adalah gejala belang berat yangmenyebabkan daun yang terinfeksi menjadi kaku; sedangkan pada genotipe PBC 521 muncul gejala belang ringan yang berupa bercak hijau yang samar pada daun, ukuran daun tetap dan tidak terjadi malformasi pada daun.

Gejala pada tanaman cabai pada perlakuan metode inokulasi tunggal maupun berulang yang diinokulasi dengan CMV lebih dahulu secara umum menimbulkan gejala mosaik dan penghambatan pertumbuhan (kerdil). Gejala mosaik berat muncul pada hampir semua tanaman pada genotipe cabai PBC 275 yang diikuti dengan pertumbuhan tanaman yang kerdil. Pada genotipe Jatilaba dan PBC 521 gejala mosaik hanya muncul pada beberapa tanaman.
Kejadian penyakit ChiVMV dan CMV berdasarkan ELISA. Berdasarkan hasil ELISA diketahui bahwa kejadian penyakit akibat infeksi ChiVMV dan CMV pada perlakuan metode inokulasi tunggal maupun berulang bervariasi antar genotipe cabai (Tabel 1 dan Tabel 2). Hasil ELISA 1 dan 2 menunjukkan hasil yang tidak berbeda, sehingga untuk evaluasi digunakan hasil ELISA 1.

Pada perlakuan metode inokulasi tunggal respon masing-masing genotipe terhadap ChiVMV atau CMV secara umum tidak dipengaruhi oleh urutan inokulasi (ChiVMV atau CMV terlebih dahulu) (Tabel 1). Genotipe PBC 275 menunjukkan kejadian penyakit tertinggi (100\%) pada semua perlakuan. Kejadian penyakit pada genotipe PBC 521 berkisar 20 sampai $80 \%$; sementara pada genotipe Jatilaba mencapai 60 sampai $100 \%$.

Kejadian penyakit pada perlakuan metode inokulasi berulang (Tabel 2) menunjukkan adanya respon yang berbeda untuk masing-masing genotipe terhadap urutan inokulasi virus. Genotipe PBC 275

Tabel 1. Kejadian penyakit pada empat genotipe cabai pada perlakuan metode inokulasi tunggal

\begin{tabular}{lllll}
\hline Genotipe & $\begin{array}{c}\Sigma \text { tanaman terineksi } \\
\text { ChiVMV }^{*} \\
(\mathrm{~A})\end{array}$ & $\begin{array}{c}\Sigma \text { tanaman terinfeksi } \\
\left.\mathrm{CMV}^{*}\right) \\
(\mathrm{A})\end{array}$ & $\begin{array}{c}\Sigma \text { tanaman terifeksi } \\
\left.\text { ChiVMV }^{*}\right)\end{array}$ & $\begin{array}{c}\Sigma \text { tanaman terinfeksi } \\
\left.\text { (MV }^{*}\right) \\
(\mathrm{B})\end{array}$ \\
\hline PBC 275 & \multicolumn{1}{c}{$25 / 25(100 \%)$} & $25 / 25(100 \%)$ & $25 / 25(100 \%)$ & $25 / 25(100 \%)$ \\
PBC 521 & $15 / 25(60 \%)$ & $10 / 25(40 \%)$ & $20 / 25(80 \%)$ & $5 / 25(20 \%)$ \\
VC 246 & $0 / 25(0 \%)$ & $0 / 25(0 \%)$ & $0 / 25(0 \%)$ & $0 / 25(0 \%)$ \\
Jatilaba & $15 / 25(60 \%)$ & $25 / 25(100 \%)$ & $20 / 25(80 \%)$ & $20 / 25(80 \%)$ \\
\hline
\end{tabular}

*) Jumlah tanaman positif ELISA/jumlah tanaman yang diinokulasi (persentase)

$\mathrm{A}=$ urutan inokulasi ChiVMV - CMV

$\mathrm{B}=$ urutan inokulasi $\mathrm{CMV}-\mathrm{ChiVMV}$

Tabel 2. Kejadian penyakit pada empat genotipe cabai pada perlakuan metode inokulasi berulang

\begin{tabular}{lllll}
\hline Genotipe & $\begin{array}{c}\Sigma \text { tanaman terinfeksi } \\
\text { ChiVMV }^{*} \\
(\mathrm{~A})\end{array}$ & $\begin{array}{c}\Sigma \text { tanaman terinfeksi } \\
\left.\mathrm{CMV}^{*}\right) \\
(\mathrm{A})\end{array}$ & $\begin{array}{c}\Sigma \text { tanaman terinfeksi } \\
\text { ChiVMV }^{*}\end{array}$ & $\begin{array}{c}\Sigma \text { tanaman terinfeksi } \\
\left.\mathrm{CMV}^{*}\right) \\
(\mathrm{B})\end{array}$ \\
\hline PBC 275 & $25 / 25(100 \%)$ & $20 / 25(80 \%)$ & $25 / 25(100 \%)$ & $15 / 25(60 \%)$ \\
PBC 521 & $25 / 25(100 \%)$ & $10 / 25(40 \%)$ & $25 / 25(100 \%)$ & $5 / 25(20 \%)$ \\
VC 246 & $0 / 25(0 \%)$ & $0 / 25(0 \%)$ & $0 / 25(0 \%)$ & $0 / 25(0 \%)$ \\
Jatilaba & $25 / 25(100 \%)$ & $5 / 25(20 \%)$ & $25 / 25(100 \%)$ & $10 / 25(40 \%)$ \\
\hline
\end{tabular}

\footnotetext{
*) Jumlah tanaman positif ELISA/jumlah tanaman yang diinokulasi (persentase)

$\mathrm{A}=$ urutan inokulasi ChiVMV - CMV - ChiVMV - CMV

$\mathrm{B}=$ urutan inokulasi CMV - ChiVMV - CMV - ChiVMV
} 
dan PBC 521 terinfeksi 100\% oleh ChiVMV baik pada perlakuan inokulasi ChiVMV terlebih dahulu maupun CMV terlebih dahulu. Infeksi CMV pada kedua genotipe tersebut cenderung lebih tinggi bila tanaman diinokulasi ChiVMV terlebih dahulu. Hal yang berbeda terlihat pada respon genotipe Jatilaba. Jumlah tanaman yang terinfeksi CMV lebih tinggi bila dilakukan inokulasi CMV terlebih dahulu.

Hasil ELISA untuk tanaman-tanaman genotipe VC 246 mendukung hasil pengamatan terhadap gejala. Tanaman-tanaman genotipe VC 246 yang diinokulasi dengan metode inokulasi tunggal maupun berulang tidak menunjukkan gejala, demikian pula hasil ELISAnya menunjukkan reaksi negatif terhadap antibodi CMV maupun ChiVMV.

Metode penapisan yang efektif diperlukan dalam kegiatan pemuliaan tanaman. Metode penapisan pada cabai yang dilakukan terhadap lebih dari satu virus secara terpisah untuk masing-masing virus membutuhkan materi penelitian yang banyak. Riyanto (2007) membutuhkan 50 tanaman untuk tiap genotipe yang diuji terhadap 2 virus yang berbeda secara terpisah. Penapisan ketahanan yang dilakukan secara bersama-sama terhadap lebih dari satu virus terbukti sangat efisien karena membutuhkan materi penelitian yang lebih sedikit. Pada penelitian ini digunakan 25 tanaman untuk tiap genotipe untuk pengujian 2 virus.

Faktor efisiensi menjadi hal yang sangat penting dalam metode penapisan pada program pemuliaan tanaman yang umumnya melibatkan banyak plasma nutfah. Oleh karena itu dalam penelitian ini juga dilakukan perbandingan antara metode inokulasi tunggal dengan berulang. Pada metode inokulasi tunggal dilakukan inokulasi dengan masing-masing virus (ChiVMV atau CMV) hanya satu kali pada tanaman yang diuji; sedangkan pada metode inokulasi berulang masing-masing virus diinokulasi dua kali. Berdasarkan kebutuhan bahan dan waktu pelaksanaan dapat disimpulkan bahwa inokulasi tunggal lebih efisien dibandingkan inokulasi berulang. Walaupun demikian perlakuan inokulasi tunggal dan berulang menyebabkan respon yang berbeda untuk tiap genotipe cabai.

Berdasarkan masa inkubasi diketahui bahwa pengaruh inokulasi tunggal dan inokulasi berulang tidak berbeda pada genotipe PBC 275 dan Jatilaba; sedangkan pada genotipe PBC 521 masa inkubasi dengan inokulasi berulang lebih cepat dibandingkan dengan inokulasi tunggal.

Secara umum metode inokulasi berulang menghasilkan kejadian penyakit yang lebih tinggi dibandingkan inokulasi tunggal pada genotipe PBC 275 dan PBC 521. Hal yang berbeda terjadi pada genotipe Jatilaba dimana urutan inokulasi virus maupun metode inokulasi tidak mempengaruhi kejadian penyakit. Memperhatikan kecenderungan respon tanaman tersebut maka metode inokulasi berulang lebih disarankan untuk digunakan sebagai metode penapisan ketahanan tanaman cabai terhadap CMV dan ChiVMV.

Inokulasi CMV dan ChiVMV secara bersamasama pada tanaman cabai sangat mempengaruhi gejala yang muncul. Subekti et al. (2006) melaporkan bahwa gejala yang timbul lebih berat pada tanaman cabai yang terinfeksi ganda CMV dan ChiVMV dibandingkan dengan infeksi secara tunggal. Pengamatan gejala pada genotipe PBC 275, PBC 521, dan Jatilaba yang diinokulasi dengan ChiVMV dan CMV menunjukkan gejala yang berat.

Dilaporkan pula oleh Subekti et al. (2006) bahwa pada saat CMV dan ChiVMV diinokulasikan bersama pada tanaman cabai ternyata konsentrasi ChiVMV selalu lebih tinggi daripada CMV. Hal yang sama diperoleh dalam penelitian ini dimana jumlah tanaman yang terinfeksi ChiVMV cenderung lebih tinggi baik pada urutan inokulasi ChiVMV maupun CMV terlebih dahulu. Hal tersebut berkaitan dengan kemampuan kedua virus untuk memanfaatkan tanaman inang dalam melakukan proses replikasi dan translokasi (Hull, 2002).

\section{SIMPULAN}

Gejala yang muncul pada infeksi ganda ChiVMV dan CMV merupakan gejala campuran antara belang dan mosaik serta malformasi daun. Gejala penyakit cenderung lebih cepat muncul pada perlakuan inokulasi dengan CMV lebih dahulu, baik pada metode inokulasi tunggal maupun berulang. Walaupun demikian berdasarkan ELISA diketahui bahwa infeksi ChiVMV cenderung lebih tinggi dibandingkan CMV baik pada metode inokulasi tunggal maupun berulang. Dalam melakukan penapisan ketahanan tanaman cabai terhadap ChiVMV dan CMV disarankan menggunakan metode inokulasi berulang dengan perlakuan inokulasi ChiVMV terlebih dahulu. 


\section{SANWACANA}

Penelitian ini merupakan bagian dari penelitian kerjasama antara Fakultas Pertanian Institut Pertanian Bogor dengan Asian Vegetable Research and Development Center (AVRDC-Taiwan). Pada kesempatan ini penulis mengucapkan terimakasih atas dukungan dana penelitian yang diberikan.

\section{DAFTAR PUSTAKA}

Clark, M.F. \& A.N. Adams. 1977. Characteristics of the microplate method of enzyme-linked immunosorbent assay for the detection of plant viruses. J of General Virol 34: 475-483.

[Ditjen Hort] Direktorat Jenderal Bina Produksi Hortikultura. 2007. Perkembangan luas panen sayuran tahun 1996-2005. http://www.deptan.go.id. [20 April 2007]

Dijkstra, J. \& C.P. de Jager. 1998. Practical Plant Virology. Protocol and Exercises. New York: Springer-Verlag Berlin Heidelberg.

Dolores, L.M. 1996. Management of pepper viruses. Di dalam: Proceeding of The AVNET II Final WORKSHOP; Philippines 21-25 Februari 1995. Tainan: AVRDC. hlm 334-342.

Green, S.K. \& J.S. Kim. 1994. Sources of resistance to viruses of pepper (Capsicum spp.): A catalog. Technical Bulletin No. 20. Asian Vegetable Research and Development Center.

Hull, R. 2002. Matthews’ Plant Virology. Ed ke-4. San Diego: Academic Press.

Laemmlen, F. 2004. Viruses in pepper. Central coast agriculture highlights. Santa Barbara County. University of California Cooperative Extension.

http://www.central.coast.agriculture.highlights6 523.pdf. [22 juli 2006].
Niks, R.E. \& W.H. Lindhout. 2006. Breeding for Resistance Against Diseases and Pest. Wangeningen: Wangeningen University Laboratory of Plant Breeding.

Riyanto, A. 2007. Studi Genetik Karakter Hortikultura dan Ketahanan terhadap Cucumber mosaic virus dan Chilli veinal mottle virus pada Cabai (Capsicum annuum L.) [tesis]. Bogor: Sekolah Pascasarjana, IPB.

Subekti, D., S.H. Hidayat, E. Nurhayati, \& S. Sujiprihati. 2006. Infeksi Cucumber mosaic virus dan Chilli veinal mottle virus terhadap pertumbuhan dan hasil tanaman cabai. Hayati 13(2):53-57.

Taufik, M. 2005. Cucumber mosaic virus dan Chilli veinal mottle virus : karakterisasi isolat cabai dan strategi pengendaliannya [disertasi]. Bogor: Sekolah Pascasarjana, IPB.

Taufik, M., S.H. Hidayat, G. Suastika, S.M. Sumaraw, \& S. Sujiprihati. 2005. Kajian Plant Growth Promoting Rhizobacteria sebagai agens proteksi Cucumber mosaic virus dan Chilli veinal mottle virus pada cabai. Hayati 12(4):139-144.

Yunianti, R. 2007. Analisis genetik pewarisan sifat ketahanan cabai (Capsicum annuum L.) terhadap Phytophthora capsici LEONIAN [disertasi]. Bogor: Sekolah Pascasarjana, IPB.

Zhang, D. 2005. Sequence variability of Cucumber mosaic virus (CMV) and its effects on CMV resistance of Capsicum sp. [dissertation]. Hamburg: Fachbereich Biologie, Universitat Hamburg. 